\title{
Perihilar Bile Duct Cancer cM1 TNM
} Finding v8

National Cancer Institute

\section{Source}

National Cancer Institute. Perihilar Bile Duct Cancer CM1 TNM Finding v8. NCI Thesaurus.

Code C134717.

Perihilar bile duct cancer with distant metastasis. (from AJCC 8th Ed.) 